\title{
Study on the Pathogenesis of Porcine Serum-Induced Liver Fibrosis in Rats with Special Reference to the Effects of Hypertension
}

\author{
Atsushi SHIGA ${ }^{1)}$, Kinji SHIROTA ${ }^{1,3)}$, Toshiho NISHITA ${ }^{2,3)}$ and Yasuo NOMURA ${ }^{1)}$ \\ ${ }^{1}$ Departments of Veterinary Pathology, ${ }^{2}$ Veterinary Physiology, and ${ }^{3}$ Research Institute of Biosciences, School of Veterinary Medicine, \\ Azabu University, 1-17-71 Fuchinobe, Sagamihara, Kanagawa 229, Japan
}

(Received 4 February 1997/Accepted 25 August 1997)

\begin{abstract}
To investigate the pathogenesis of porcine serum (PS)-induced liver fibrosis in rats, two experiments were carried out, taking into consideration of hypertension and vascular changes. In Experiment I, spontaneous hypertensive rats (SHRs), two-kidney, one clip hypertensive F344 rats (2K1C rats), and normotensive F344 rats were given an intraperitoneal injection of PS of $0.5 \mathrm{~m} l$ twice a week for 8 weeks. Histopathological, immunohistochemical, and electron microscopical examinations were performed on the liver from each rat. Histological features of liver fibrosis in hypertensive and normotensive rats were essentially identical. However, in the PS-treated SHRs, 2 of 5 animals showed the most severe fibrosis in all PS-treated groups. Electron microscopically, degranulated mast cells, eosinophils, and macrophages engulfing apoptotic cells were rarely observed in the late stage of fibrous septa (FS) in the PS-treated SHR liver. In Experiment II with normotensive F344 rats, histopathological features of early FS in the liver were compared with those of late FS observed in Experiment I using serial sections, and we found that FS developed along the wall of newly formed vessels to connect between neighboring central veins. However, the effect of hypertension on this fibrosis could not be clearly demonstrated in the present study using SHRs and 2K1C rats. - KEY wORDs: liver fibrosis, porcine serum, renal hypertensive rat, spontaneous hypertensive rat.
\end{abstract}

J. Vet. Med.Sci. 60(1): 29-34, 1998

It has been suggested that the disturbance of portal circulation plays a role in the pathogenesis of porcine serum (PS)-induced liver fibrosis in rats [20]. In this model, capillarization and venularization of sinusoids coincided with fibrosis, and these phenomena were considered to be an adaptation for maintenance of blood flow in hepatic lobules [2]. Angiotensin II stimulates hypertrophic growth of vascular smooth muscle cells (SMCs) [9]. On the other hand, angiotensin-converting enzyme inhibitor captopril has been demonstrated to inhibit an experimental fibrosis in various organs [13, 19, 22] and growth of fibroblasts in vitro [14]. The PS-induced liver fibrosis in rats was also attenuated by captopril [18]. In nonhuman primates with experimentally induced hypertension, the myocardium produced a collagen without necrosis at an early stage as a reactive change [23]. Fibrosis also occurred as a reactive change against gradual hepatocellular necrosis/apoptosis in the liver of rats given a repetitive intraperitoneal injection of PS [20].

It is possible that hypertension may participate in the pathogenesis of this liver fibrosis. Administration of histamine $\mathrm{H}_{1}$ receptor antagonist mepyramine suppressed this liver fibrosis [11], suggesting some role for mast cells in local histamine release. Therefore, in the present study, we examined the effect of hypertension on PS-induced liver fibrosis in rats, using spontaneous hypertensive rats (SHRs) and two-kidney, one clip (2K1C) hypertensive rats in which the maintenance of hypertension is dependent on the reninangiotensin system [15]. In addition, to investigate the involvement of IgE as a trigger of histamine release in PSinduced liver fibrosis in rats, we measured serum IgE concentration and examined the distribution of IgE-positive cells in the liver.

\section{MATERIALS AND METHODS}

Animals: Male SHRs and Fischer 344/NS1c (F344) rats were obtained from Japan SLC Inc. (Shizuoka, Japan). The rats were housed (two or three per cage) in polycarbonate cages and maintained under controlled conditions (temperature, $23 \pm 2{ }^{\circ} \mathrm{C}$; humidity, $60 \pm 5 \%$ ). Commercial diet (CE-7, CLEA Japan Inc., Tokyo, Japan) and tap water were supplied ad libitum. The rats were euthanized by exsanguination via the abdominal aorta 7 days after the last injection of PS under ether anesthesia in each experiment. Serum samples were collected from all rats used in the present study and stored at $-20^{\circ} \mathrm{C}$ until analysis.

Experiment I: Ten SHRs, 6 2K1C F344 rats, and 6 shamoperated F344 rats were used for this experiment. They were divided into five groups at 8 weeks of age as shown in Table 1. Under sodium pentobarbital anesthesia, 2K1C rats were produced by partial occlusion of the left renal artery with a silver clip (inside diameter: $0.2 \mathrm{~mm}$ ), while the right renal artery was left intact. Blood pressure was measured by non-invasive, blood pressure measuring equipment for laboratory mice and rats (Muromachi Kikai Co., Ltd., Tokyo, Japan). These rats were given an intraperitoneal injection of $0.5 \mathrm{~m} l$ of PS (JRH Biosciences, Lunexa, KS., U.S.A., Lot No. 4K2178) twice a week for 8 weeks. Control rats were given physiological saline alone. As for $2 \mathrm{~K} 1 \mathrm{C}$ rats, only animals with systolic blood pressure greater than $200 \mathrm{mmHg}$ that all SHRs showed were used.

Experiment II: To examine morphological alterations in early stage of fibrosis, 10 normotensive F344 rats were given 
Table 1. Histological grade of fibrosis

\begin{tabular}{|c|c|c|c|c|c|}
\hline & Group & Inoculum $^{\text {a) }}$ & No. of rats & Rat No. & $\begin{array}{l}\text { Extent of } \\
\text { fibrosis }{ }^{b)}\end{array}$ \\
\hline \multirow{6}{*}{$2 \mathrm{~K} 1 \mathrm{C}$ rat } & \multirow{3}{*}{ I } & \multirow{3}{*}{ S } & \multirow{3}{*}{3} & 1 & \pm \\
\hline & & & & 2 & \pm \\
\hline & & & & 3 & \pm \\
\hline & \multirow{3}{*}{ II } & \multirow{3}{*}{ PS } & \multirow{3}{*}{3} & 1 & + \\
\hline & & & & 2 & ++++ \\
\hline & & & & 3 & +++ \\
\hline \multirow{10}{*}{ SHRs } & \multirow{5}{*}{ III } & \multirow{5}{*}{ S } & \multirow{5}{*}{5} & 1 & - \\
\hline & & & & 2 & - \\
\hline & & & & 3 & - \\
\hline & & & & 4 & - \\
\hline & & & & 5 & - \\
\hline & \multirow{5}{*}{ IV } & \multirow{5}{*}{ PS } & \multirow{5}{*}{5} & 1 & $++++^{*}$ \\
\hline & & & & 2 & $++++*$ \\
\hline & & & & 3 & + \\
\hline & & & & 4 & ++++ \\
\hline & & & & 5 & + \\
\hline \multirow{6}{*}{$\begin{array}{l}\text { Sham- } \\
\text { operated } \\
\text { rats }\end{array}$} & \multirow{6}{*}{$\mathrm{V}$} & \multirow{6}{*}{ PS } & \multirow{6}{*}{6} & 1 & - \\
\hline & & & & 2 & ++++ \\
\hline & & & & 3 & ++ \\
\hline & & & & 4 & +++ \\
\hline & & & & 5 & ++++ \\
\hline & & & & 6 & + \\
\hline
\end{tabular}

a) S: physiological saline, PS: porcine serum. b) Literature cited: [6]. -: None, \pm : Very slight. +: Slight, short collagenous septa extended from central veins. ++: Moderate, slender septa link the central veins, but lobular architecture is preserved. +++: Marked, pseudolobuli are formed by thin septa. ++++: Severe, parenchyma is subdivided into smaller pseudolobuli by thin septa. ++++*: Very severe, smaller pseudolobuli formation by thick septa.

a PS injection for 5 or 6 weeks in the same manner as Experiment I. Five rats for each duration of treatment were used. In this experiment, only morphological examinations on early FS were performed.

These experiments were approved by the Animal Care Committee at Azabu University.

Histopathology: The left lateral lobe of the liver was removed from each rat in both experiments, fixed in $10 \%$ phosphate buffered formalin, and embedded in paraffin following standard operating procedures. Paraffin sections were cut $3 \mu \mathrm{m}$ in thickness and stained with hematoxylin and eosin (HE) and also with several special stains including Masson's trichrome stain, periodic acid-Schiff (PAS) reaction with diastase digestion, Schmorl's ferricferricianide reduction stain, toluidine blue ( $\mathrm{pH} 4.1)$ stain, and Perls' Prussian blue stain. In addition, histopathological comparison between the late (Experiment I) and early (Experiment II) fibrous septa (FS) was also performed on serial sections. The extent of hepatic fibrosis was evaluated according to Fujiwara's description [6] with slight modification.

Immunohistochemistry: Immunohistochemical examination was performed on 2 rats per group in
Experiment I. Immunostaining was carried out by the labeled streptavidin-biotin methods using a Histofine kit (Nichirei Corp., Tokyo, Japan). Primary antibodies used were anti-human $\alpha$-smooth muscle actin ( $\alpha$-SMA) antibody (Sigma Chemical Co., St. Louis, MO, U.S.A.), anti-bovine type I collagen antibody (LSL Co., Ltd., Tokyo, Japan), anti-bovine type III collagen antibody (LSL Co., Ltd.), antirat type IV collagen antibody (kindly supplied by Drs. Ito, M. and Arai, K.), and peroxidase-conjugated anti-rat IgE antibody (Nordic Immunological Laboratories, Tilburg, Netherlands). For immunostaining with anti-collagen antibody and anti-IgE antibody, methacarn fixative $(60 \%$ methanol, 30\% chloroform, 10\% glacial acetic acid) was used. After blocking of endogenous peroxidase activity with $3 \%$ hydrogen peroxide in deparaffinized sections, pretreatment with $0.1 \%$ trypsin in $0.1 \mathrm{M}$ phosphate buffer saline (PBS) (pH 7.4) was performed for $1 \mathrm{hr}$ at $37^{\circ} \mathrm{C}$ for IgG immunostaining. Then, normal rabbit or goat serum were applied to the sections to inhibit non-specific reaction. The sections were treated sequentially with primary antibody for $1 \mathrm{hr}$ at $37^{\circ} \mathrm{C}$, biotinylated rabbit anti-mouse $\mathrm{IgG}$ or goat anti-rabbit $\mathrm{IgG}$ for $10 \mathrm{~min}$ each at room temperature, then peroxidase-labeled streptavidin for $15 \mathrm{~min}$ at room temperature, and finally with 3,3'-diaminobenzidine in 0.1 $\mathrm{M}$ Tris $\mathrm{HCl}$ buffer ( $\mathrm{pH}$ 7.6) containing hydrogen peroxide. The sections were washed with $0.1 \mathrm{M}$ PBS ( $\mathrm{pH}$ 7.4) after each step and counterstained with Mayer's hematoxylin.

Electron microscopy: Electron microscopic examination was performed on 2 rats per group in Experiment I. Small blocks $\left(1 \mathrm{~mm}^{3}\right)$ of the left lateral lobe of the liver were fixed in $2.5 \%$ glutaraldehyde/0.1 M phosphate buffer $(\mathrm{pH}$ 7.4) for $2 \mathrm{hr}$ at $4^{\circ} \mathrm{C}$, post-fixed in $1 \%$ osmium tetroxide $/ 0.2$ $\mathrm{M}$ phosphate buffer ( $\mathrm{pH} 7.4$ ) for $2 \mathrm{hr}$ at $4^{\circ} \mathrm{C}$, dehydrated in graded ethanol, and embedded in epoxy resin. Semi-thin sections were cut, stained with toluidine blue, and examined by light microscope to find the object fields. Then, ultrathin sections were cut and double stained with uranyl acetate and lead citrate, and examined with a Hitachi H-300 transmission electron microscope (Hitachi Ltd., Tokyo, Japan) at $75 \mathrm{kV}$.

Passive cutaneous anaphylaxis test (PCA): The dorsal skin hair of 13-week-old male F344 rats was removed under pentobarbital anesthesia and $50 \mu l$ of test sera was injected intradermally. Five rats were used and the maximal number of serum samples that applied to one rat was 5 . After $24 \mathrm{hr}$, $1 \mathrm{ml}$ of equal parts of PS and 3\% Evans blue (Wako Pure Chemical Industries, Ltd., Osaka, Japan)/physiological saline was injected intravenously through the tail vein. The rats were euthanized by exsanguination via the abdominal aorta $30 \mathrm{~min}$ after the injection and the blue spot appeared in the skin of the injection site and more than $5 \mathrm{~mm}$ in diameter were judged as positive. This test was performed on serum samples from all rats in Experiment I.

Dot blotting method: Test sera and IgE (Chemicon International Inc., Temecula, CA, U.S.A.) were applied to nitrocellulose sheet $(0.45 \mu \mathrm{m}$ pore size, Type TM-2, Toyo Roshi Co., Ltd., Japan) using a multimicro filtration system 
(DOT PLATE). The rat sera and standard IgE diluted with 0.1 M PBS ( $\mathrm{pH} 7.6$ ) were subjected in duplicate to dot blotting assay. Non-specific reaction was blocked with $5 \%$ bovine serum albumin (Sigma Chemical Co.) in 0.1 M PBS at room temperature for $1 \mathrm{hr}$. Thereafter, peroxidaseconjugated goat anti-rat IgE antibody was applied to the membrane and incubated at $4{ }^{\circ} \mathrm{C}$ overnight. The membrane was washed three times for 5 min with PBS containing Tween 20 (Wako Pure Chemical Industries, Ltd.) with shaking by mixer after each step. The immunoreaction was visualized with 3,3'-diaminobenzidine in $0.1 \mathrm{M}$ Tris $\mathrm{HCl}$ buffer ( $\mathrm{pH}$ 7.6) and hydrogen peroxide. This assay was also applied for serum samples from all rats in Experiment I.

\section{RESULTS}

Clinical signs: No significant clinical signs were observed in any group of PS-treated rats for each experiment.

Histopathology: In Experiment I, hepatic septal fibrosis connecting neighboring central veins (CVs) was induced in all animals in PS-treated groups II, IV, and V. Histological changes in the liver of all PS-treated rats were characterized by infiltration of fibroblastic cells, mast cells, eosinophils, and macrophages containing hemosiderin and/or lipofuscin in wide FS. In addition, thickening of most of portal vein branches resulting in narrowing lumen was also observed in all PS-treated rats, but not in saline-treated animals. The extent of fibrosis in each rat was shown in Table 1. Histological features of liver fibrosis in PS-treated hypertensive rats were essentially identical to those of normotensive rats. Hypertrophy of SMCs in the interlobular arteries was noted in all hypertensive rats independent of liver fibrosis. In $2 \mathrm{~K} 1 \mathrm{C}$ rats, hypertrophy of SMCs around CVs was noted irrespective of PS injection. Comparison of major histological findings of rat liver from Experiment I were summarized in Table 2.

In group I, fibrosis around $\mathrm{CVs}$ (perivenular sclerosis) was observed, but mild fibrotic change extending from these CVs (perivenular fibrosis) was rarely found. This perivenular fibrosis did not accompany by cellular reaction. In group II, hypertrophy and migration of SMCs were observed around CVs and vessels in more advanced stages of FS (Figs. 1a, b). In group III, no abnormalities were detected in the liver. In group IV, 2 of 5 rats exhibited the most severe fibrosis in all PS-treated groups (Figs. 2a, b) (Table 1). In the liver from some rats of group IV, mast cells around CVs and in FS were apparently less in number than in the other PS-treated rats. Histopathological observation on serial sections of the liver with late FS revealed that FS developed along the walls of newly formed vessels between neighboring CVs.

In Experiment II, liver fibrosis was induced in 7 of 10 rats. The extent of liver fibrosis was slight (early FS) in 6 rats and mild in 1 rat. Early FS also developed along the walls of newly formed vessels between neighboring CVs (Figs. 3a, b) as seen in late FS.
Table 2. Comparison of main histological findings in rat liver from Experiment I

\begin{tabular}{|c|c|c|c|c|c|}
\hline \multirow[t]{2}{*}{ Group } & \multicolumn{2}{|c|}{ Fibrous change } & \multicolumn{3}{|c|}{ SMC hypertrophya) } \\
\hline & $\begin{array}{l}\text { perivenular }^{\text {b) }} \\
\text { sclerosis }\end{array}$ & $\begin{array}{l}\text { perivenularc } \\
\text { fibrosis }\end{array}$ & $\mathrm{CV}$ & $\mathrm{PV}$ & IA \\
\hline $2 \mathrm{~K} 1 \mathrm{C}$ rats $\mathrm{I}$ & $+^{\mathrm{d})}$ & $\pm^{\mathrm{e})}$ & + & - & + \\
\hline II & + & + & + & + & + \\
\hline \multirow[t]{2}{*}{ SHRs } & - & - & - & - & + \\
\hline & + & + & - & + & + \\
\hline $\begin{array}{l}\text { Sham- V } \\
\text { operated } \\
\text { rats }\end{array}$ & + & + & - & + & - \\
\hline
\end{tabular}

a) CV: Central vein, PV: Portal vein branch, IA: Interlobar artery. b) fibrosis around CV. c) Fibrosis extending from CV. d) +: Present, -: Not present. e) \pm : Very slight and without evident cellular reaction.

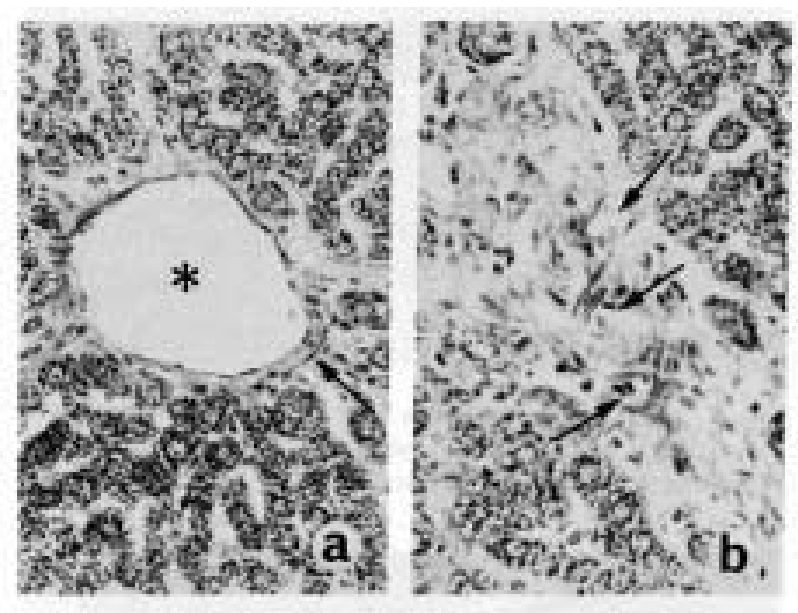

Fig. 1. PS-treated 2K1C rat (Experiment I, group II). Phosphotangustic acid hematoxylin stain. (a) SMCs around $\mathrm{CV}(*)$ showing hypertrophy and migration (arrow). $\times 520$. (b) SMCs (arrows) migrating around the remaining sinusoids. $\times 800$.

Immunohistochemistry: Types I, III, and IV collagens were demonstrated in the early and late FS. The immunoreactivity of type IV collagen in FS was more intense as compared with the other portions such as sinusoids, even at early FS. IgE-positive cells were mostly observed in the portal areas of the liver from both salineand PS-treated rats and were occasionally encountered around CVs of the PS-treated rat liver. The IgE-positive cells in the PS-treated rat liver were greater in number than those of the saline-treated rat liver. Most of the IgE-positive cells corresponded to mast cells (Figs. $4 \mathrm{a}, \mathrm{b}$ ), and very rarely to eosinophils.

Electron microscopy: Vascular endothelial cells within FS (Fig. 5a) were multilayered and outlined by many fibroblastic cells (Fig. 5b). Some of these fibroblastic cells contained a few lipid droplets (Fig. 5a) and their cytoprocesses were closely attached to each other (Fig. 5b). 

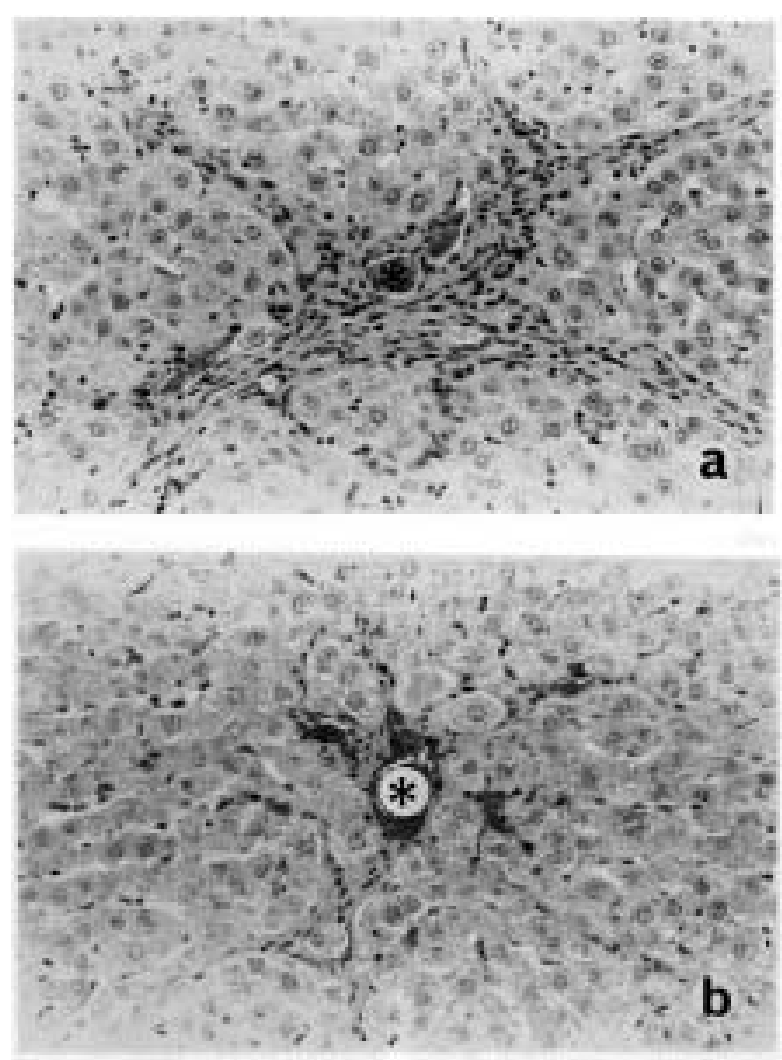

Fig. 2. Perivenular fibrosis in SHR (Experiment I, group IV) (a) and in sham-operated rat (Experiment I, group V) (b). central vein (asterisks). HE stain. $\times 400$.
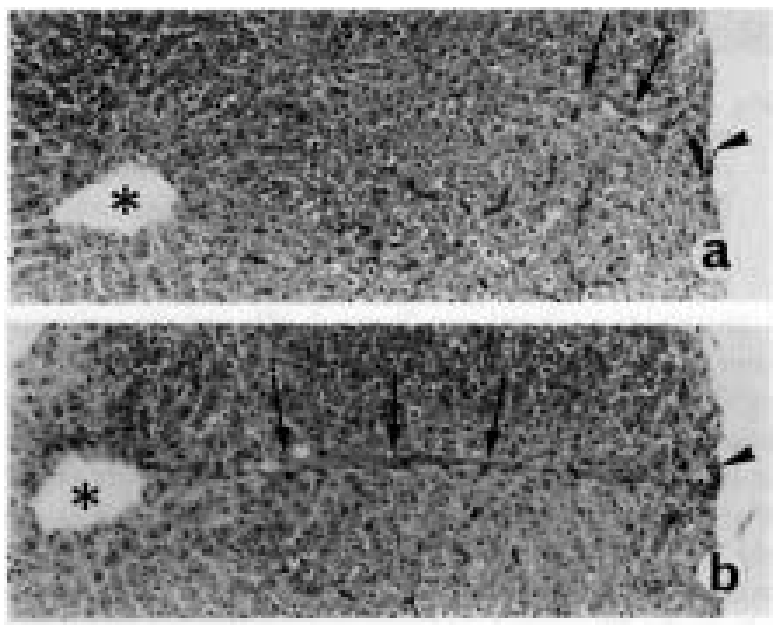

Fig. 3. Serial sections with early FS. 6-weeks-treated F344 rat (Experiment II). (a) Early FS (arrows) originating from subcapsular CV. (b) Blood vessel (arrows) observed in FS. $\mathrm{CV}$ within parenchyma (asterisks), subcapsular CV (arrowheads). HE stain. $\times 220$.

Degranulated mast cells, eosinophils, and macrophages engulfing apoptotic cells were rarely found in FS.

PCA test: No positive reaction was observed in the PS-
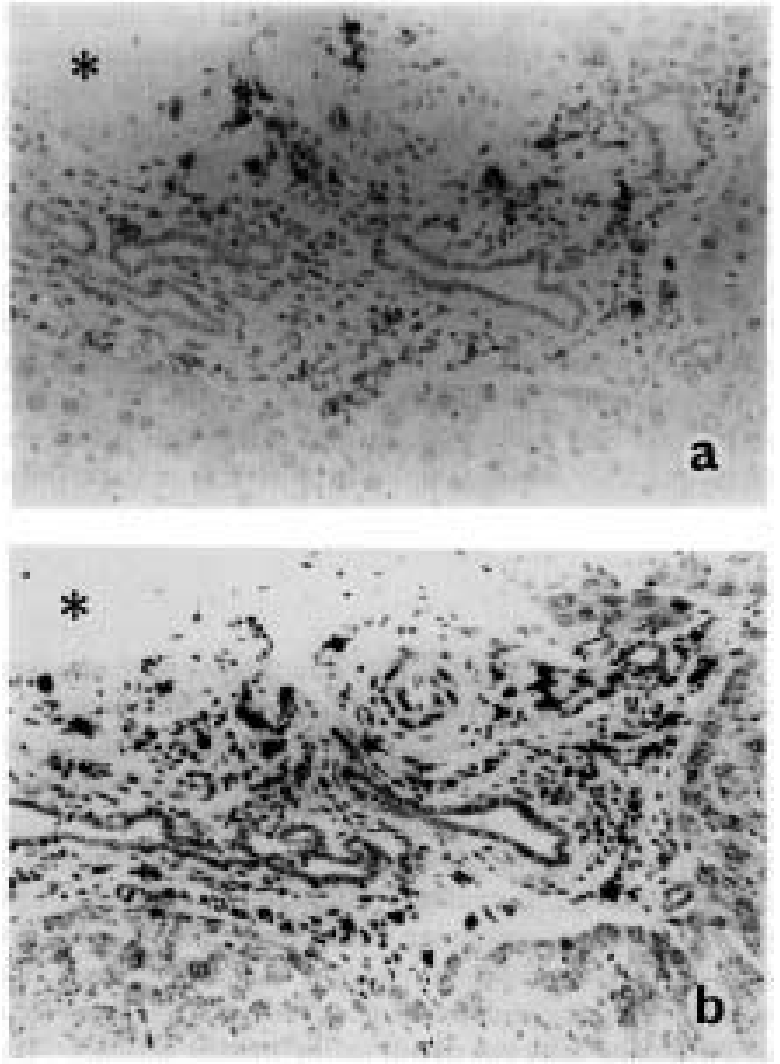

Fig. 4. Serial sections showing accordance of the most of $\operatorname{IgE}$ positive cells with metachromatic mast cells. (a): The portal area from treated rat liver (Experiment I). IgE immunostaining with Mayer's hematoxylin counterstain. (b): Toluidine blue $(\mathrm{pH} 4.1)$ stain. Portal vein (asterisks). $\times 430$.

treated rats examined.

Dot blotting method: Serum IgE concentrations in all rats serum in Experiment I investigated were less than the detection limit of $15 \mathrm{ng} / \mathrm{ml}$. Thus, the differences in concentration between saline-and PS-treated rats could not be detected by the present method.

\section{DISCUSSION}

In the present study, we suspected participation of hypertension in the development of PS-induced liver fibrosis and investigated the effect of hypertension in this liver fibrosis using two kinds of hypertensive rats (SHRs and 2K1C F344 rats). Most of the results in this study, however, failed to clearly demonstrate such an effect. The extent of fibrosis in some SHRs appeared to be more severe than that of $2 \mathrm{~K} 1 \mathrm{C} \mathrm{F} 344$ rats. This result may be due to the strain difference in PS-induced liver fibrosis and is independent of blood pressure, since in vivo study demonstrated that vascular SMCs from SHRs were more sensitive to growth stimuli [7].

In the PS-treated $2 \mathrm{~K} 1 \mathrm{C}$ rats, SMCs around CVs showed a hypertrophic change. Moreover, migration and increase 

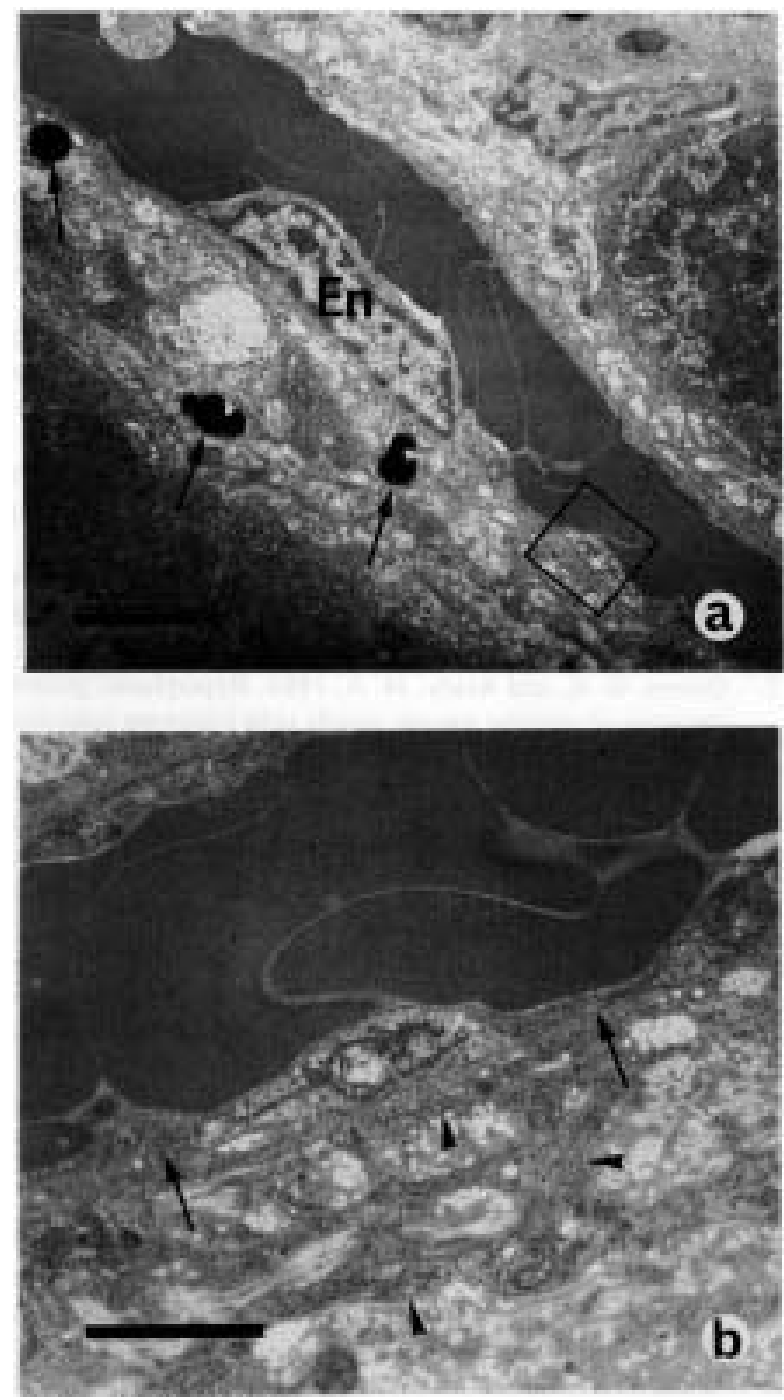

Fig. 5. FS from PS-treated SHR (Experiment I, group IV). a) Vessels in FS surrounded by Ito cells (arrows). b) High power view of open black square of Fig. 5a. Multilayered vascular endothelial cell (arrows) and many septal fibroblastic cells (arrowheads), equivalent to pericytes. Electronmicrograph stained by uranyl acetate and lead citrate. Bar= a) $5 \mu \mathrm{m}$, b) 2 $\mu \mathrm{m}$.

in number of SMCs around CVs and vessels in more advanced FS were observed. Such changes were not observed in sham-operated rats. Since proliferation of vascular SMCs is considered to be a phenomenon following elevated blood pressure [17], these changes in SMCs may be interpreted as an adaptive response to elevation of blood pressure in the liver. The origin of these SMCs is uncertain in the present study, but they may derive from septal $\alpha$ SMA-positive cells in this model [20]. Kay et al. [10] described transformation of myofibroblast-like cells into SMCs in the lung with severe pulmonary hypertension. Migration of activated Ito cells has also been suggested in the PS-treated liver fibrosis model [5].
Endothelial cells may be one of the candidates to mediate migration or differentiation of SMCs, because endothelial cells may react to the physical stimulus of fluid shear stress and stimulate SMCs migration and enhance collagen production of endothelial cells themselves [16]. Gene expression of extracellular matrices (ECMs) was shown to increase preferentially in rat Ito cells and sinusoidal endothelial cells (SECs) during hepatic fibrosis in vivo [12]. Type IV collagen deposition was reported to be predominant in ECMs at early stage of PS-induced liver fibrosis [1]. Similar immunohistochemical results on ECMs were obtained in the present study. In contrast, major type of collagen in early $\mathrm{FS}$ of $\mathrm{CCl}_{4}$-treated rat liver is type III [21], suggesting the type of collagen increasing in FS to be dependent on the causative factors of fibrosis. SECs may be one of the collagen producers in this model.

The presence of degranulated mast cells and eosinophils may indicate local interaction between IgE and these cells in this liver fibrosis, because these cells have IgE-specific receptors on their surfaces $[3,8]$. An increase in IgEpositive mast cells in the liver of PS-treated rats was evidenced in this study, especially in the portal areas. However, the specificity of IgE to PS was unknown. An increase in serum IgE in PS-treated rats could not be demonstrated because of a detection limit in the method used $(15 \mathrm{ng} / \mathrm{ml})$ and the wide range of serum IgE levels in normal rats $(0.5$ to $20 \mathrm{ng} / \mathrm{ml})$ [4]. In fact, administration of antagonist to histamine $\mathrm{H}_{1}$ receptor but not to $\mathrm{H}_{2}$ receptor suppressed this liver fibrosis [11].

We have previously shown indirect evidence of necrosis/ apoptosis of hepatocytes in this model [20]. That evidence might represent hepatocellular injury due to hypoxia or to develop secondary to remodeling of intrahepatic vessels following hemodynamic changes in the intrahepatic circulation.

In conclusion, the effect of hypertension on this fibrosis could not be clearly demonstrated in the present study using SHRs and $2 \mathrm{~K} 1 \mathrm{C}$ rats. FS in this model might be formed concomitant with shunts that developed to effectively supply oxygen for hepatocytes located between neighboring CVs. Disturbance of portal circulation following narrowing of the lumen of the portal vein branches due to histamine release from mast cells can be suspected as the cause and trigger of the hypoxic condition of the hepatocytes in this model.

ACKNOWLEDGEMENTS. We would like to acknowledge Dr. Makoto Enomoto (Biosafety Research Center, Foods, Drugs, and Pesticides, Shizuoka, Japan) for valuable suggestions and for reviewing this manuscript. We also would like to express our gratitude to Dr. Jun Yamakoshi (Kikkoman Corp., Chiba, Japan) for technical advice on 2K1C rats, Kikkoman Corp. (Chiba, Japan), who kindly provided non-invasive blood pressure measuring equipment and Drs. Masaaki Ito and Katsuhiko Arai (Department of Scleroprotein Chemistry and Cell Biology, Tokyo University of Agriculture and Technology) for kindly providing valuable antibody against rat type IV collagen, and Mrs. 
Roslyn Hayman (Department of Pathology, Azabu University) for correcting grammatical errors of this manuscript.

\section{REFERENCES}

1. Ballardini, G., Faccani, A., Fallani, M., Berti, S., Visi, V., Castaldini, C., Biagini, G., Garbisa, S. and Bianchi, F. B. 1985. Sequential behaviour of extracellular matrix glycoproteins in an experimental model of hepatic fibrosis. Virchows Arch. B (Cell Pathol.) 49: 317-324.

2. Bhunchet, E. and Fujieda, K. 1993. Capillarization and venularization of hepatic sinusoids in porcine serum-induced rat liver fibrosis: A mechanism to maintain liver blood flow. Hepatology 18: 1450-1458.

3. Capron, M., Capron, A., Dessaint, J.-P., Torpier, G., Johanson, S. G. O. and Prin, L. 1981. Fc receptor for IgE on human and rat eosinophils. J. Immunol. 126: 2087-2092.

4. Carter, P. B. and Bazin, H. 1980. Immunology. pp. 181-212. In: The Laboratory Rat, vol. II (Baker, H. J. et al. eds.), Academic Press, New York.

5. Cenacchi, G., Ballardini, G., De Giorgi, L. B., Busachi, C. A., Del Rosso, M., Bianchi, F. B., Biagini, G. and Laschi, R. 1983. Relationship between connective tissue cells and fibronectin in a sequential model of experimental hepatic fibrosis. Virchows Arch. B (Cell Pathol.) 43: 75-84.

6. Fujiwara, K., Ogata, I., Ohta, Y., Hayashi, S., Mishiro, S., Takatsuki, K., Sato, Y., Yamada, S., Hirata, K., Oka, H., Oda, T., Kawaji, H., Matsuda, S., Niijima, Y. and Tsukuda, R. 1988. Decreased collagen accumulation by a prolyl hydroxylase inhibitor in pig serum-induced fibrotic rat liver. Hepatology 8: 804-807.

7. Hamet, P., Hadrava, V., Kruppa, U. and Tremblay, J. 1988. Vascular smooth muscle cell hyper-responsiveness to growth factors in hypertension. J. Hypertension 6 (Suppl. 4): S36S39.

8. Ishizaka, K., Tomioka, H. and Ishizaka, T. 1970. Mechanisms of passive sensitization. I. Presence of $\operatorname{IgE}$ and $\mathrm{IgG}$ molecules on human leukocytes. J. Immunol. 105: 1459-1467.

9. Itoh, H., Mukoyama, M., Pratt, R. E., Gibbons, G. H. and Dzau, V. J. 1993. Multiple autocrine growth factors modulate vascular smooth muscle cell growth response to angiotensin II. J. Clin. Invest. 91: 2268-2274.

10. Kay, J. M., Kahana, L. M. and Rihal, C. 1996. Diffuse smooth muscle proliferation of the lungs with severe pulmonary hypertension. Hum. Pathol. 27: 969-974.

11. Kurebayashi, Y., Ikeda, T. and Nagata, Y. 1987. Proceeding of the Seventy-Sixth Annual Meeting of the Japanese Patho- logical Society, Tokyo, p. 259 (in Japanese).

12. Maher, J. J. and McGuire, R. F. 1990. Extracellular matrix gene expression increases preferentially in rat lipocytes and sinusoidal endothelial cells during hepatic fibrosis in vivo. $J$. Clin. Invest. 86: 1641-1648.

13. Molteni, A., Ward, W. F. Ts'ao, C.-H., Solliday. N. H. and Dunne, M. 1985. Monocrotaline-induced pulmonary fibrosis in rats: Amelioration by captopril and penicillamine. Proc. Soc. Exp. Biol. Med. 180: 112-120.

14. Nagai, M., Arino, T., Tsuchiya, M., Takeda, N. and Nagano, M. 1992. The inhibitory effects of captopril on the growth of various cultured cells (abstract). J. Mol. Cell. Cardiol. 24 (Suppl. 1): 244.

15. Okamura, T., Miyazaki, M., Inagami, T. and Toda, N. 1985. Vascular renin-angiotensin system in two-kidney, one clip hypertensive rats. Hypertension 8: 560-565.

16. Ono, O., Ando, J., Kamiya, A., Kuboki, Y. and Yasuda, H. 1991. Flow effects on cultured vascular endothelial and smooth muscle cell functions. Cell Struc. Func. 16: 365-374.

17. Owens, G. K. and Reidy, M. A. 1985. Hyperplastic growth response of vascular smooth muscle cells following induction of acute hypertension in rats by aortic coarctation. Circ Res. 57: 695-705.

18. Ramos, S. G., Montenegro, A. P., Goissis, G. and Rossi, M. A. 1994. Captopril reduces collagen and mast cell and eosinophil accumulation in pig serum-induced rat liver fibrosis. Pathol. Inter. 44: 655-661.

19. Rossi, M. A. and Peres, L. C. 1992. Effect of captopril on the prevention and regression of myocardial cell hypertrophy and interstitial fibrosis in pressure overload cardiac hypertrophy. Am. Heart J. 124: 700-709.

20. Shiga,A., Shirota, K., Ikeda, T. and Nomura, Y. 1997. Morphological and immunohistochemical studies on porcine serum-induced rat liver fibrosis. J. Vet. Med. Sci. 59: 159167.

21. Takahara, T., Kojima, T., Miyabayashi, C., Inoue, K., Sasaki, H., Muragaki, Y. and Ooshima, A. 1988. Collagen production in fat-storing cells after carbon tetrachloride intoxication in the rat. Lab. Invest. 59: 509-521.

22. Ward, W. F., Molteni, A., Ts'ao, C.-H. and Hinz, J. M. 1990. Captopril reduces collagen and mast cell accumulation in irradiated rat lung. Int J. Radiation Oncology Biol. Phys. 19: 1405-1409.

23. Weber, K. T., Janicki, J. S., Shroff, S. G., Pick, R., Chen, R. M. and Bashey, R. I. 1988. Collagen remodeling of the pressure-overloaded, hypertrophied nonhuman primate myocardium. Circ. Res. 62: 757-765. 